\title{
NUMERICAL SIMULATIONOF FLEXIBLE WINGOF HALE UAV USING TWO-WAY FLUID STRUCTURE INTERACTION METHOD
}

\author{
Buyung Junaidin \\ Teknik Penerbangan \\ Sekolah Tinggi Teknologi Adisutjipto \\ Jl.Janti Blok R Lanud Adisutjipto Yogyakarta \\ Ikh_libi_dikh $(a$ yahoo.com
}

\begin{abstract}
This paper describes numerical simulation of flexible High Altitude Long Endurance Unmanned Aerial Vehicle (HALE UAV)wingusing two-way fluid structure interaction (FSI) method. The HALE wing is designed with high aspect ratio. This configuration intended to reduce the vehicle induced drag and reduces the lift-loss at wingtip which caused by wingtip vortex. But the structure of the wing itself becomes more elastic that be able to give large deformation when the aerodynamic loads applied. This deformation changes the aerodynamic loads distribution on the wing that gives a new deformation to the wing structure and vice versa. This interaction in a couple process called as fluid structure interaction (FSI). ANSYS 15.0 software was used to simulate fluid structure interaction on the wing. The unsteadiness and viscous flows at low speed are evaluated using the solution of timedependent Reynolds Averaged Navier-Stokes (RANS) with SST $k-\omega$ turbulent model. In addition, multiblock structured grids are generated to provide more accurate viscous result and to anticipate negative volume of the mesh which may occur due to the deformation of the wing during simulation. Five different of simulations are performed with variation of material characteristics including Young's modulus and Poisson's ratio. The results are global aerodynamic characteristics at various material characteristics.
\end{abstract}

Keyword: High Altitude Long Endurance (HALE); two-way FSI method; Wing Aerodynamic characteristics; Young 's modulus; Poisson's ratio

\begin{abstract}
ABSTRAK
Penelitian ini menjelaskan tentang simulasi numerik dari sayap Fleksibel High Altitude Long Endurance Unmanned Aerial Vehicle (HALE UAV) menggunakan metode interaksi fluida-struktur dua-arah. Sayap pesawat HALE didesain dengan aspek rasio besar. Konfigurasi ini mengurangi induce drag dan kehilangan lift pada ujung sayap akibat vortek pada ujung sayap. Akan tetapi, hal ini juga menyebabkan struktur sayap menjadi lebih elastis yang dapat menghasilkan deformasi besar ketika mendapat gaya aerodinamika. Deformasi ini menyebabkan perubahan distribusi beban aerodinamika pada sayap sehingga menghasilkan deformasi baru pada struktur sayap itu sendiri dan sebaliknya. Interaksi ini terjadi terus menerus secara berpasangan dan dikenal dengan istilah interaksi fluida struktur. Software ANSYS 15.0 digunakan untuk melakukan simulasi interaksi fluida struktur pada sayap pesawat. Aliran tak tunak dan viskos pada kecepatan rendah analisis dengan solusi timedependent Reynolds Averaged Navier-Stokes (RANS) dan model turbulentSST k- $\omega$. Selain itu, grid terstruktur multi-blok dibuat untuk akurasi hasil pada aliran viskos dan untuk mengantisipasi munculnya volum negatif dari mesh yang mungkin terjadi akibat adanya deformasi sayap selama simulasi. Lima simulasi berbeda dilakukan dengan variasi karakteristik material berupa modulus
\end{abstract}


elastisitas dan rasio Poisson. Hasil simulasi menunjukkan karakteristik aerodinamika sayap terhadap variasi karakteristik material.

Kata kunci : High Altitude Long Endurance (HALE); metode interaksi fluida struktur dua-arah; Karakteristik aerodinamika sayap; Modulus elastisitas; Rasio Poisson

\section{Introduction}

Recent research trends have indicated an interest on development of High Altitude Long Endurance (HALE) Unmanned Aerial Vehicle (UAV). It is shown by number of HALE UAVs both operational and technology demonstration types have been developed or are currently under development. Examples of some developed and under development HALE UAV in the world are shown in figure 1.

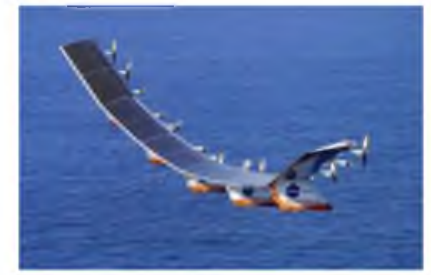

Helios-NASA

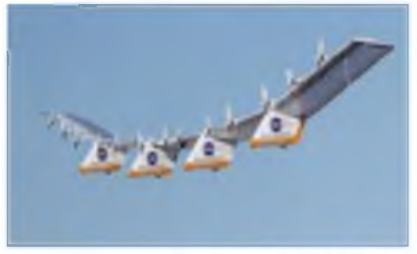

Centurion-NASA

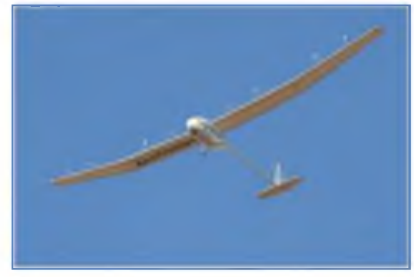

Global observer

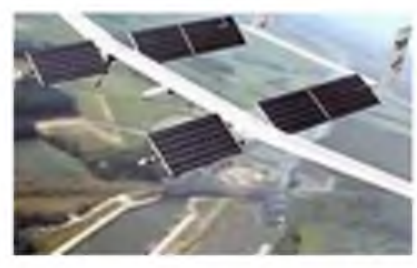

Solitair-Germany

Figure 1 High altitudes and long endurance UAVs examples

Interest in the development of HALE reasonable because it can be used as a low-cost alternative to space missions, such as scientific data collection, telecommunication relay, environmental sensing, surveillance and military reconnaissance. In order to achieve these missions, the aircraft must be capable of operating at extremely high altitudes to obtain maximum coverage. In addition, the aircraft must also be capable of extended mission duration. To fulfill the long-endurance requirement, the UAV must be designed to have high aerodynamic efficiency and light weight structure. These conditions can be reached by application of high-aspect ratio wing.

Application of high-aspect ratio wing give the advantage that it can reduce the vehicle induced drag, but the structure of the wing itself becomes more elastic that be able to give large deformation when the aerodynamic loads applied. This deformation changes the aerodynamic loads distribution on the wing that gives a new deformation to the wing structure and vice versa. This interaction in a couple process called as fluid structure interaction (FSI).

Research on the fluid structure interaction hasbeen done by several researchers in any fields. In the field of aerospace, FSI theory was used by Garelli et al. (2010) for rocket engine 
nozzle and for airfoil by Ramji and Wei (2004). Furthermore, a loosely coupled FSI scheme was used by Dang et al. (2010) for an aeroelastic wing problem for high aspect ratio using constant volume tetrahedron interfacing technique for coupling computational fluid dynamics (CFD) and computational structural dynamics (CSD). Moreover, Chen et al. (2007) use fully coupled FSI scheme for 3D wing flutter analysis. They showed the importance of reliable and efficient flutter analysis for airplane wings and aircraft-engine turbo-machinery blades.

The main purpose of this research was to simulate the flexible HALE wing for aerodynamic characteristics using two-way FSI method. Five different of simulations are performed with variation of material characteristic including Young's modulus and Poisson's ratio. In this research, ANSYS software was used to simulate fluid structure interaction on the wing. In ANSYS, simulation was performed between transient structural (ANSYSMechanical) and fluid flow (ANSYS-CFX) in workbench, as given in ANSYS-workbench. The CSD obtains aerodynamic loadings through fluid solid interface at the wing surfaces from ANSYS-CFX. The deformed shape from CSD is further coupled with CFD, from which new loadings are determined. This iterative process is continued until a suitable level of convergence is achieved. The coupling between CFD and CSD are almost impossible for complex geometry because the two-way FSI solution takes more computational power and time due to the strong coupling scheme. This research provides only basic knowledge of FSI due to computational power and time constraint.

\section{Fluid Structure Interaction}

Fluid structure interaction (FSI) occurs when a fluid interacts with a solid structure, exerting pressure on it which may cause deformation in the structure. As a return, the deformed structure alters the flow field. The altered flowing fluid, in turn exerts another form of pressure on the structure with repeat of the process.

The main FSI solution approaches can be divided roughly into monolithic (fully coupled, simultaneous) methods and partitioned (staggered, iterative) methods (Paik, K. J., 2010). The monolithic methods tightly couple fluid and structural discrete equations and solve them together. The partitioned methods solve each field separately and solution variables are passed iteratively from field to field until convergence is achieved. The partitioned method is further divided into two major categories: one-way and two-way coupling. Two-way can be further divided into a loose (weak) and strongly coupled method. Weakly coupled method is use if a structure in the flow field or containing flowing fluid deforms slightly or vibrates with small amplitude. Strongly coupled method is use if alteration of the flow filed due to large deformation or high amplitude vibration of the structure cannot be neglected.

FSI problems can be solved using one-way or two-way FSI techniques (Benra, F.K. et al, 2011). In one-way FSI, the fluid field is solved only for the pressure forces, and these pressure forces are later applied on the body in solid or structure analyses to obtain the stresses. The flow field altered due to structural deformation when fluid analysis is ignored. It is also assumed that no displacement/deformation is produced during fluid analysis. While in two-way FSI, the pressure forces as well as displacement produced when fluid analysis is transferred to the structural analysis for stresses, and structural results for pressure forces are 
again the input for fluid analysis. This process of data sharing between structural and fluid field continues until a suitable level of convergence is achieved

\section{Multi-field Simulation Modeling}

In ANSYS-workbench multi-field, simulation was performed between transient structural (ANSYS-Mechanical) and fluid flow (CFX-Pre); both models were developed independently. Each model requires independent mesh, boundary condition, analysis options, and output options, etc. In the present case the ANSYS-CFX works as a master code. It reads all commands, including interface meshes from the ANSYS-Mechanical code, maps and communicates time, and stagger loop controls to the ANSYS Mechanical code.

\subsection{Transient Structural Physics and Modeling}

For mechanical application, the setting transient structural (ANSYS) window is dragged first in ANSYS-workbench. 3D modeling of the HALE wing is undertaken in CATIA V5 software with the parameter specifications as shownin table 1 .

Table 1 Wing model specification.

\begin{tabular}{|c|c|c|}
\hline No & Parameter & Design Model \\
\hline 1 & $\mathrm{C}(\mathrm{m})$ & inner wing:0.4 at root and tip \\
& & outer wing:0.4 at root and 0.25 at tip \\
\hline 2 & $\mathrm{y}(\mathrm{m})$ & inner wing:4.2 \\
& & outer wing: 1.5 \\
\hline 3 & Wing aerofoil & EMX-07 \\
\hline 4 & A (deg) & inner wing:0 and outer wing:4.2 at $0.25 \mathrm{C}$ \\
\hline 5 & $\Gamma(\mathrm{deg})$ & inner wing:0 and outer wing:9.8 at LE \\
\hline
\end{tabular}

The geometry is imported into transient structural window. Initial analysis is performed using steel with the following fundamental properties: $\rho=7850 \mathrm{~kg} / \mathrm{m} 3, E=2.0 \times 1011 \mathrm{~N} / \mathrm{m} 2$, and $v=0.3$. In mechanical application, the solid body, wing is meshed. For mesh sizing, the following properties are used: relevance center (fine), smoothing (high), and transition (slow). Transition affects the rate at which adjacent elements will grow. Slow transition produces smooth transitions, while the fast results in more sudden transitions. Span angle center (high) is applied for wing leading edge. This is used for wing leading edge curvature refinement. 


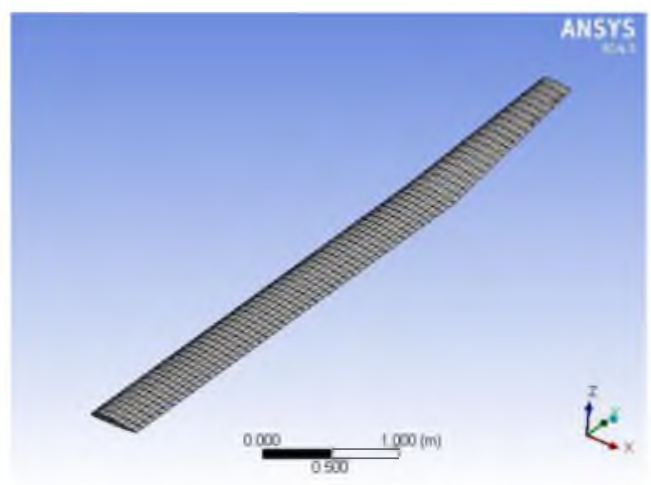

Figure 2 Mesh of solid body

The simulation will be performed for five different material characteristics.

Table 2 Material characteristics comparison.

\begin{tabular}{|c|c|c|c|}
\hline \multirow{2}{*}{ No } & \multirow{2}{*}{ Materials } & \multicolumn{2}{|c|}{ Characteristics } \\
\cline { 3 - 4 } & & $\mu$ & E (Gpa) \\
\hline 1 & Steel & 0.30 & 200 \\
\hline 2 & A & 0.30 & 20 \\
\hline 3 & B & 0.30 & 2 \\
\hline 4 & C & 0.40 & 2 \\
\hline 5 & D & 0.49 & 2 \\
\hline
\end{tabular}

The input boundary conditions are : fixed support at the wing root position and fluid solid interface at wing is applied. Figure 3 shows inputs defined in ANSYS-Mechanical.

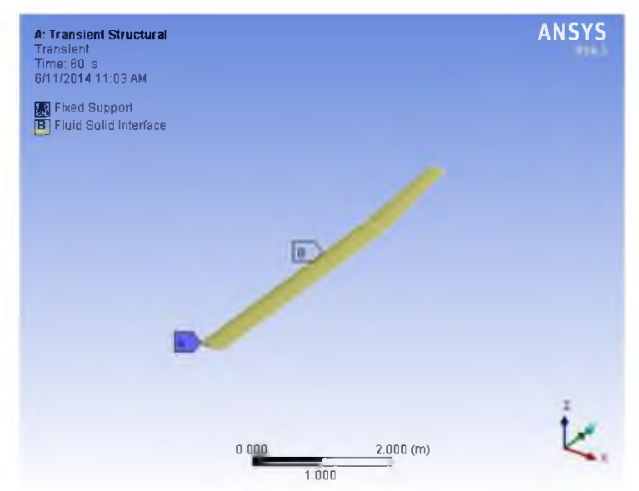

Figure 3 Transient structural physics 
Next, the analysis setting is reset for a total time of 60 second with time step option of 0.025 second and the program control solver is selected. This is an optimal solver. Because the other solver, i.e., the direct solver, is used for thin flexible models, and the iterative solver is used for bulky models.

\subsection{Fluid flow (CFX) physics and modeling}

In fluid flow (CFX) modeling, the CFX window is dragged and attach with transient structural window. All the physics and data will be shared with this window. In fluid flow (CFX), the geometry and the mesh of fluid body is undertaken in ANSYS-ICEM.

The flow defined as air ideal gas and considered as transient flow. The flow is taken to be viscous, turbulent, incompressible and isothermal (without heat transfer). Isothermal assumption can be used because temperature difference between the wing and ambient is very small. Turbulence model that be used is shear stress transport (SST) model. The SST model unifies the advantages of the most widely employed two-equation (k- $\varepsilon$ and $k-\omega)$ models and is the most reliable model for fluid with flow separation. Incompressible assumption is used because simulation running at low air speed.

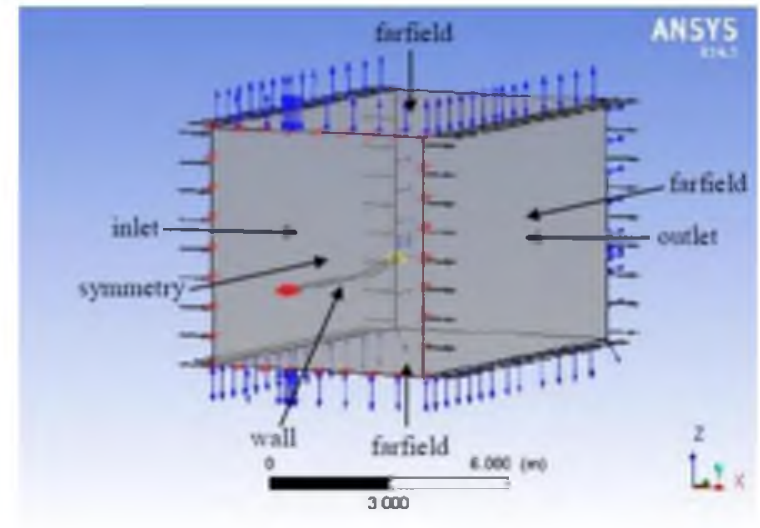

Figure 4 CFX Simulation model with boundary condition.

All the boundary conditions (inlet, outlet, wall, and farfield) are defined using named selection option in ICEM setup. Boundary type 'wall' is defined with mass and momentum option of 'no-slip wall'. This condition is by default, indicating that the fluid sticks to the wall and moves with the same velocity at the wall. Furthermore, outlet and farfield boundary conditions are defined with relative pressure and opening pressure respectively equal to zero.Coupling time duration of 60 second with time step of 0.025 second and transient analyses are also defined in this simulation. Physical parameters are used in CFX is determined from free stream condition based on HALE UAV operation altitudes, 20000 feet (Moelyadi, M. A. et all, 2013). 
Table 3 Physical parameters in CFX.

\begin{tabular}{|c|c|c|}
\hline No & $\begin{array}{c}\text { Physical } \\
\text { Parameters }\end{array}$ & Values \\
\hline 1 & $\mathrm{~T}_{\mathrm{s}}$ & $248.5 \mathrm{~K}$ \\
\hline 2 & $\mathrm{P}_{\mathrm{s}}$ & $46562 \mathrm{~N} / \mathrm{m}^{2}$ \\
\hline 3 & $\rho$ & $0.653 \mathrm{~kg} / \mathrm{m}^{3}$ \\
\hline 4 & $\mathrm{u}$ & $17.88 \mathrm{~m} / \mathrm{s}$ \\
\hline
\end{tabular}

\section{Results and Discussion}

Simulations of flexible HALE wing for aerodynamic characteristics using two-way FSI method are done with variation of material characteristic including Young's modulus and Poisson's ratio. The results are global aerodynamic characteristics at various material characteristics.

\subsection{Lift}

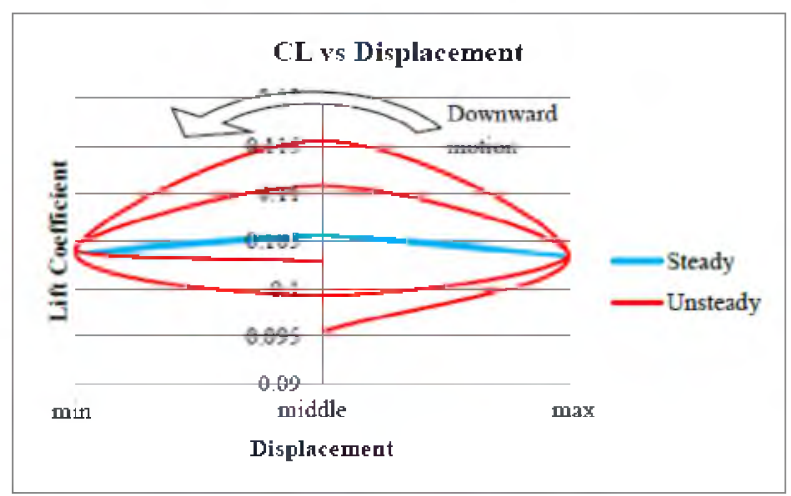

Figur 5 Lift coefficient of wing for steady and unsteady simulation

Figure 5 shows the lift coefficient result of unsteady aerodynamic characteristics of the wing and quasi-steady simulation result. When look at the unsteady curve, upper line of lift coefficient during downward motion and lower line is during upward motion. Compared to the quasi-steady result, the unsteady result gives additional lift coefficient during downward motion. This is caused by upward induced velocity which is occurred because of downward motion. The maximum additional lift coefficient occurred when the wing in the middle position. While, during the upward motion the decrement of lift coefficient occurred. This is caused by downward induced velocity which is occurred because of upward motion. The minimum decrement of lift coefficient occurred when the wing in the middle position. The differences of lift coefficient magnitude at maximum and minimum displacement between unsteady simulation and steady simulation are not significant because there are no induced velocity occurred. 


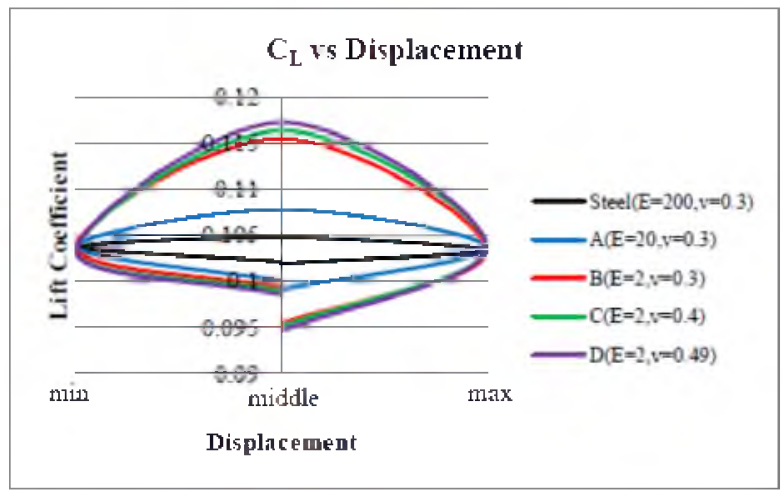

Figur 6 Lift coefficient of wing at various materials

Figure 6 shows the effect of material characteristics to the lift coefficient. Lift coefficient increases with decreasing of Young's modulus during downward motion. During upward motion, decreasing of Young's modulus makes decrement of lift coefficient.

Consider to the effect of Poisson's ratio, lift coefficient increases with increasing of Poisson's ratio during downward motion. During upward motion, increasing of Poisson's ratio makes decrement of lift coefficient. The maximum of increment and decrement of lift coefficient occurs at middle position when the maximum local velocity is produced. Effect of variation of Poisson's ratio to the increment and decrement of lift coefficient is not as much as Young's modulus effect.

\subsection{Drag}

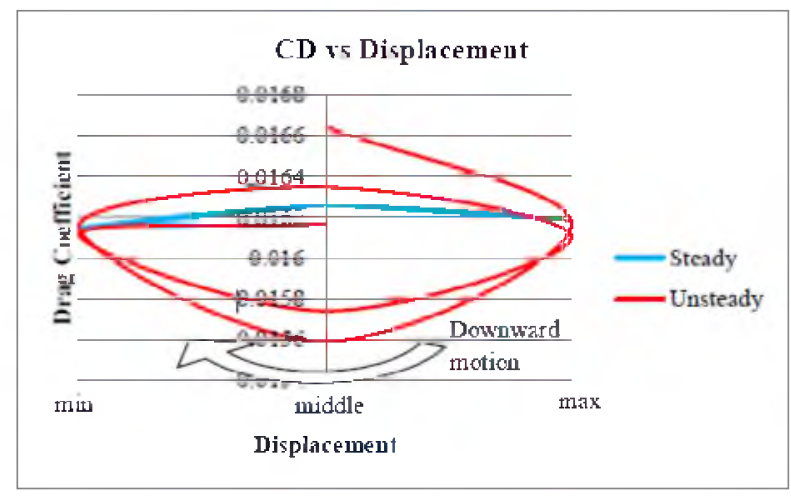

Figur 7 Drag coefficient of wing for steady and unsteady simulation

Figure 7 shows drag coefficient results of unsteady aerodynamic characteristics of the wing and quasi-steady simulation result. When look at the unsteady curve, the upper line of drag coefficient result is upward motion and the lower line of drag coefficient result is downward motion. Compared to the quasi-steady result, unsteady result gives high decrement of drag coefficient during downward motion and makes increment of drag coefficient during the upward motion. Additional drag coefficient when upward motion is not as much as decrement drag coefficient during downward motion. 


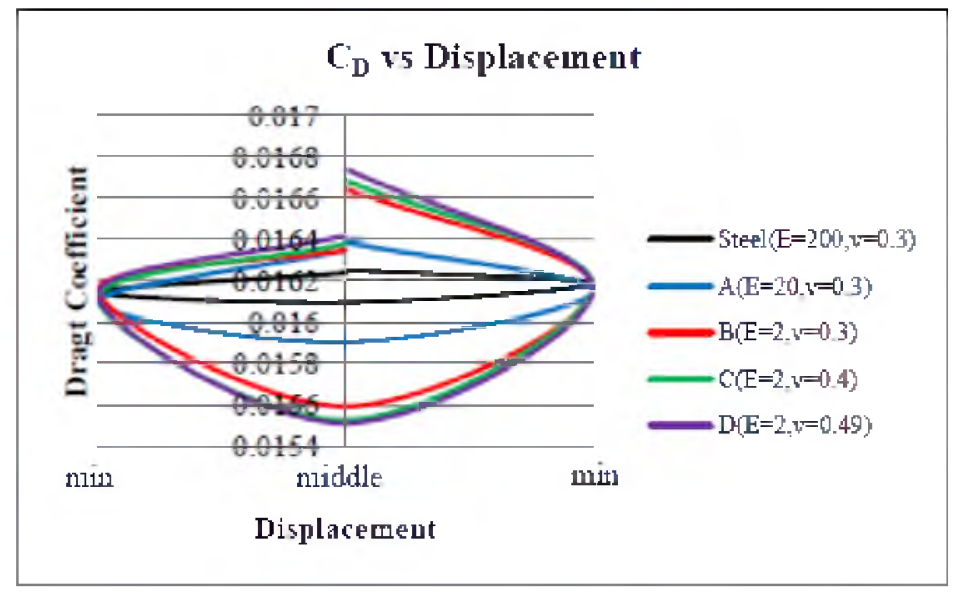

Figur 8 Drag coefficient of wing at various materials

During downward motion, decreasing of Young's modulus causes large decrease in drag coefficient, and it give good effect to the aerodynamic performance. During upward motion, decreasing of Young's modulus makes increment of drag coefficient but not as much as decrement of drag coefficient during downward motion.

Consider to the effect of Poisson's ratio, drag coefficient decreases with increasing of Poisson's ratio during downward motion. During upward motion, increasing of Poisson's ratio makes increment of drag coefficient. Effect of variation of Poisson's ratio to the increment and decrement of drag coefficient is not as much as Young's modulus effect.

\subsection{Flow Physics}

To explain the result of global aerodynamics thoroughly it needed to describe the detail aspects. Those aspects are velocity around the wing. The velocity around the wing as the result from the deformation of the wing and free steam velocity.

Figure 9show velocity contours of unsteady results at leading edge for downward motion and upward motion respectively. All compared plots of velocity contour use the same lower and upper limits of velocity magnitude.

Unsteady solution yields additional velocity at upper surface of wing during downward motion. It is happened because downward motion creates upwash induced velocity to the wing which makes velocity at upper surface of wing increases. Furthermore, velocity at upper surface of wing decreases during upward motion. It is happened because upward motion creates downwash induced velocity to the wing which makes velocity at upper surface of wing decrease. That explains during downward motion, lift coefficient increases and during upward motion, lift force decreases. 


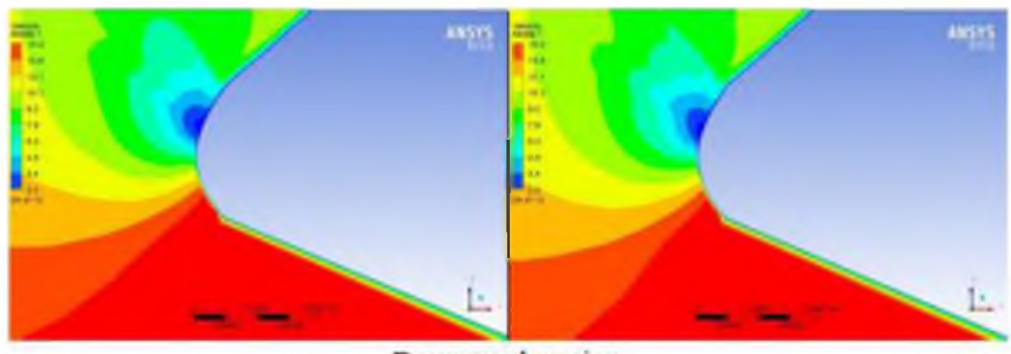

Downward motion

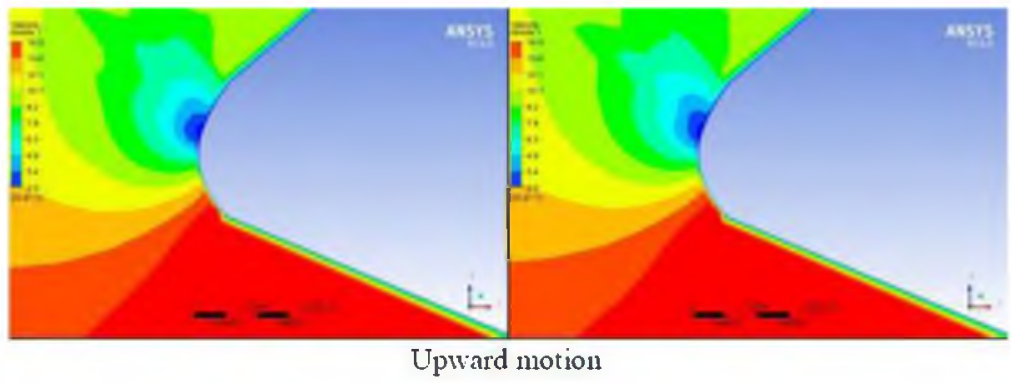

Figure 9 Velocity contour at leading edge and at $0.7 \mathrm{y}$

\section{Conclusions}

Simulations of flexible HALE wing using two-way FSI method have been done with simplify the simulation. Simulation results shows that Lift coefficient increases and drag coefficient decreases with decreasing of Young's modulus during downward motion and vice versa. Lift coefficient increases and drag coefficient decreases with increasing of Poisson's ratio during downward motion and vice versa. Effect of variation of Poisson's ratio to the increment and decrement of lift coefficient and drag coefficient is not as much as Young's modulus effect.

\section{Nomenclature}

List the nomenclature in alphabetical order. List Roman letters followed by Greek symbols followed by subscript and superscripts.

$$
\begin{aligned}
& \mathrm{C}=\text { Chord length }(\mathrm{m}) \\
& \mathrm{y}=\text { semispan }(\mathrm{m}) \\
& \Lambda \quad=\text { swept angle }(\mathrm{deg}) \\
& \Gamma \quad=\text { dihedral angle }(\mathrm{deg}) \\
& \mu \quad=\text { Poisson's ratio } \\
& \mathrm{E}=\text { Young's modulus }(\mathrm{GPa}) \\
& \rho \quad=\text { density }\left(\mathrm{kg} / \mathrm{m}^{3}\right) \\
& \mathrm{u}=\text { free stream velocity }(\mathrm{m} / \mathrm{s})
\end{aligned}
$$




$$
\begin{aligned}
& \mathrm{T}_{\mathrm{S}}=\text { static temperature } \\
& \mathrm{P}_{\mathrm{S}}=\text { static pressure } \\
& \mathrm{C}_{\mathrm{L}}=\text { lift coefficient } \\
& \mathrm{C}_{\mathrm{D}}=\text { drag coefficient }
\end{aligned}
$$

\section{References}

Nickol, C. L., et al., 2007. High Altitude Long Endurance UAV Analysis of Alternatives and Technology Requirements Development. NASA/TP-2007-214861.

Goraj, Z. et al., 2004. High altitude long endurance unmanned aerial vehicle of a new generation - a design challenge for a low cost, reliable and high performance aircraft. Buletin of the Polish Academy of Sciences Technical Sciences, Vol. 52, No. 3, 2004.

Romeo, G. Frulla, G. Cestino, E and Corsino, G., 2004. HELIPLAT: Design, Aerodynamics and Structural Analysis of Long Endurance, Solar-Powered Stratospheric Platform. Jornal of Aircraft, vol. 41, No. 6. November-December 2004.

Paik, K. J., 2010. Simulation of fluid-structure interaction for surface ships with linear/nonlinear deformations. University of Iowa, Iowa, USA.

Benra, F.K., Dohmen, H.J., Pei, J., Schuster, S., Wan, B., 2011. A comparison of one-way \& two-way coupling methodsfor numerical analysis of fluid-structure interactions. Journal of Applied Mathematics, Article ID 853560

Moelyadi, M. A., Putra, I., Junaidin, B., and Muljowidodo, 2013. CFD based Prediction of Aerodynamic Torsion Reduction of HALE UAV Wing with Wing Control Surfaces. ITB, Bandung, Indonesia.

Garelli, L., Paz, R.R., Storti, M.A., 2010. Fluid structure interaction of the start-up of a rocket engine nozzle. Journal of Computers and Fluids

Ramji, K., Wei, S., 2004. Fluid-structure interaction for aeroelastic applications. Progress in Aerospace Sciences.

Dang, H., Yang, Z., Li, Y., 2010. Accelerated loosely-coupled CFD/CSD method for nonlinear static aeroelastic analysis. Journal of Aerospace Science and Technology.

Chen, X., Zha, G.-C., Yang, M.-T., 2007. Numerical simulation of 3-D wing flutter with fully coupled fluid-structure interaction. Computers \& Fluids 36, 856-867 
Buyung Junaidin 